DOI https://doi.org/10.30525/978-9934-588-81-5-2.43

\title{
FORECASTING THE RISK FOR HUMAN HEALTH OF GROUNDWATER CONTAMINATED BY PESTICIDES TANK MIXTURES' COMPONENTS CONSUMPTION (ON THE EXAMPLE OF FUNGICIDE QUADRIS MIXTURES WITH OTHER GROUPS OF PESTICIDES)
}

\author{
Vavrinevych O.P. \\ $M D$, Professor, \\ Professor of Hygiene and Ecology Department № 1 \\ Bogomolets National Medical University \\ Antonenko A. M. \\ MD, Associate Professor, \\ Professor of Hygiene and Ecology Department № 1 \\ Bogomolets National Medical University \\ Bardov V. G. \\ Corresponding Member of the National Academy of Medical Sciences \\ of Ukraine, MD, Professor, \\ Head of the Hygiene and Ecology Department № 1 \\ Bogomolets National Medical University \\ Omelchuk S. T. \\ MD, Professor, \\ Head \\ Hygiene and Ecology Institute № 1 \\ of the Bogomolets National Medical University \\ Pelio I. M. \\ MD, Professor, \\ Professor at the Hygiene and Ecology Department № 1 \\ Bogomolets National Medical University \\ Kyiv, Ukraine
}

The results of long-term epidemiological studies conducted both in Ukraine and in a number of other developed countries show that there is a link between increasing the incidence of the population and pollution of the environment with pesticides. [1, p. 267-270; 2, p. 353-357; 3, p. 108-119; 4, p. 158-165]. 
The situation is further complicated by the fact that long-term and large-scale application of chemical plant protection products contributes to the development of resistance of harmful agents to their action, which is accompanied by reduced effectiveness of pesticides and as a result of increasing their consumption and frequency of crop treatments. In connection with the above, the leading strategic direction in the field of crops chemical protection is the development and implementation in agriculture of modern plant protection technologies, synthesis and application of new active substances and formulations based on them, combined formulation and tank mixes [5, p. 1447-1483; 6].

The results of scientific researches convincingly prove that the most effective way to prevent and eliminate resistance of pathogens is application of multicomponent pesticides tank mixtures, which also include plant growth regulators and mineral fertilizers $[7$, p. 33-37; 8, p. 54-59; 9, p. 97-107; 10, p. 84-90].

Their application leads to the weakening of harmful agents, helps to increase crop yields and significantly reduces the consumption of pesticides.

According to scientists, the use of tank mixes is an integral part of the technology of growing high yields and is a promising way to reduce the resistance of pathogens to chemical plant protection products while significantly reducing the pesticide load on the environment.

The problem is that tank mixes of pesticides are used without prior study, although their potential danger is greater than combined formulation. If the combined formulations contain several (usually 2-3) active ingredients and the necessary components of the formulation, the mixtures include ready-made formulations with their active ingredients and auxiliary components.

The above necessitates the development of a methodology and hygienic assessment of the potential danger to the population of the effects of pesticides tank mixtures' components, given the possibility of their entry into the body simultaneously with food, water and air.

The analysis of physicochemical properties, toxicological and hygienic criteria of components of 6 tank mixes of pesticides is carried out (tab. 1). Based on the results of our own field studies on the active ingredients dynamics in the soil, their degradation parameters $\left(\tau_{50}, \tau_{95}, \tau_{99}\right.$, degradation constant) were calculated, the values of which were the basis for risk assessment for the population. This risk assessment was carried out according to the integral index of contaminated water consumption (IICWC) proposed by experts of the Hygiene and Ecology Institute [11, p. 77-84].

An integrated assessment of the potential hazards of pesticides to the human body when consuming contaminated with pesticides groundwater and surface water is based on the analysis of LEACH [12, p. 69-78], half- 
life period $\left(\tau_{50}\right)$ in water [13] and the allowable daily dose (ADD) according to the proposed assessment scale, which provides four gradation (in points). Hygienic hazard assessment for humans is as follows: the integral index of contaminated water consumption (IICWC) is obtained by adding all the points and evaluated as follows: when the value of IICWC is 3 and 4 points - low hazard (class 4), 5 and 6 - moderate hazard (class 3), 7 and 8 - hazardous (class 2), 9 and 10 - highly hazardous (class 1B), 11 and 12 - extremely hazardous (class 1A).

Table 1

General characteristics of the studied pesticides mixtures

\begin{tabular}{|c|c|c|c|c|}
\hline $\begin{array}{c}\text { Mix- } \\
\text { ture } \\
\text { No. }\end{array}$ & Compounds & $\begin{array}{c}\text { Com- } \\
\text { pounds } \\
\text { ratio }\end{array}$ & $\begin{array}{c}\text { Active } \\
\text { ingredients }\end{array}$ & Purpose \\
\hline 1 & $\begin{array}{c}\text { Quadris 250 SC + } \\
\text { Aктара 25 WG }\end{array}$ & $6: 1$ & $\begin{array}{c}\text { azoxystrobine, } \\
\text { thiamethoxam }\end{array}$ & $\begin{array}{c}\text { fungicide } \\
\text { insecticide }\end{array}$ \\
\hline 2 & $\begin{array}{c}\text { Quadris 250 SC + } \\
\text { Karate Zeon 050 CS }\end{array}$ & $6: 1$ & $\begin{array}{c}\text { azoxystrobine, } \\
\text { lambda- } \\
\text { cyhalothrin }\end{array}$ & $\begin{array}{c}\text { fungicide } \\
\text { insecticide }\end{array}$ \\
\hline 3 & $\begin{array}{c}\text { Quadris 250 SC + } \\
\text { Shirlan 500 SC }\end{array}$ & $2: 1$ & $\begin{array}{c}\text { azoxystrobine, } \\
\text { fluazinam }\end{array}$ & $\begin{array}{c}\text { fungicide } \\
\text { fungicide }\end{array}$ \\
\hline 4 & $\begin{array}{c}\text { Quadris 250 SC + } \\
\text { Copper oxychloride, } \\
\text { WP }\end{array}$ & $1: 4$ & $\begin{array}{c}\text { azoxystrobine, } \\
\text { copper oxychlorid: }\end{array}$ & $\begin{array}{c}\text { fungicide } \\
\text { fungicide }\end{array}$ \\
\hline 5 & $\begin{array}{c}\text { Quadris 250 SC + } \\
\text { Cuproxat, SC }\end{array}$ & $1: 5$ & $\begin{array}{c}\text { azoxystrobine, } \\
\text { copper sulfate }\end{array}$ & $\begin{array}{c}\text { fungicide } \\
\text { fungicide }\end{array}$ \\
\hline 6 & $\begin{array}{c}\text { Quadris 250 SC+ } \\
\text { Aktellik 500 EC }\end{array}$ & $6: 15$ & $\begin{array}{c}\text { azoxystrobine, } \\
\text { pirimiphos-methyl }\end{array}$ & $\begin{array}{c}\text { fungicide } \\
\text { insecticide }\end{array}$ \\
\hline
\end{tabular}

Based on the analysis, it was found that azoxystrobin (active ingredient of Quadris formulation), which is part of all tank mixtures, as well as copper oxychloride (mixture № 4) belong to the $3^{\text {rd }}$ hazard class - moderately dangerous compounds. The components of mixtures № 2, 3, 5 - lambdacyhalothrin, fluazinam and copper sulfate (hazard class 2) are dangerous for humans. Thiamethoxam and pirimiphos-methyl (components of the mixture № 1 and 6) are highly dangerous (class 1B). The obtained results can be explained by high toxicity, persistence in water and high probability of leaching into groundwater and surface water.

The assessment of the potential danger to the population of the impact of the pesticides tank mixtures' components showed the need for control in water for all components when using the studied tank mixtures.

Taking into account the results of the risk assessment to public health when using water contaminated with pesticides tank mixtures' components, 
it is recommended to carefully control the residual amounts of studied pesticides in drinking and domestic water. In regions with intensive agricultural production, it is recommended to use the integral index of contaminated water consumption (IICWC) index to resolve the issue of monitoring studies of tank mixes in water.

\section{References:}

1. Antonenko A.M., Vavrinevych O.P., Korshun M.M., Omelchuk S.T. Hygienic assessment of the effects of pesticides Application on children population morbidity With thyroid gland diseases Wiadomości Lekarskie. 2019. Tom LXXII. Nr 2. P. 267-270.

2. Antonenko A.M., Vavrinevych O.P., Korshun M.M., Omelchuk S.T. Hygienic assessment of the effects of pesticides application on adult population morbidity with thyroid gland diseases. Wiadomości Lekarskie. 2018. Tom LXXI. Nr 2. cz II. P. 353-357.

3. Michalovicz L.T., Kelly K.A., Sullivan K., O'Callaghan J.P. Acetylcholinesterase inhibitor exposures as an initiating factor in the development of Gulf War Illness, a chronic neuroimmune disorder in deployed veterans. Neuropharmacology. 2020. № 17. P. 108-119.

4. Nankongnab N., Kongtip P., Tipayamongkholgul M. [et al.]. Difference in accidents, health symptoms, and ergonomic problems between conventional farmers using pesticides and organic farmers. J Agromed. 2020. № 25(2). P. 158-165.

5. Nuruzzaman Md., Rahman M.M., Yanju Liu, Ravi N. Nanoencapsulation, Nano-guard for Pesticides: A New Window for Safe Application . Agric. Food Chem. 2016. № 64 (7). P. 1447-1483.

6. Davydov R., Sokolov M., Hogland W. [et al.]. The application of pesticides and mineral fertilizers in agriculture. International Scientific Conference on Energy, Environmental and Construction Engineering (EECE-2018). MATEC Web of Conferences. 2018. Vol. 245, 5 p.

7. Москаленко В.Ф., Пельо І.М., Омельчук С.Т. [та ін.]. Наукове обгрунтування методичних підходів до здійснення санітарного нагляду за застосуванням сумішей пестицидів в овочівництві. Украӥнський журнал з проблем медицини прациi. 2013. № 2 (35). С. 33-37.

8. Москаленко В.Ф., Пельо І.М., Омельчук С.Т. [та ін.] Особливості санітарного контролю продуктів овочівництва та грунту при застосуванні сумішей пестицидів. Світ медицини та біологіï. 2014. № 1(43). C. 54-59.

9. Пельо І.М., Бардов В.Г., Вавріневич О.П. Токсикологогігієнічна оцінка бакових сумішей пестицидів та встановлення їх лімітуючих компонентів для оптимізації санітарного нагляду. Медична наука Украӥни. 2015. Т. 11. № 3-4. С. 99-107. 
10. Пельо І.М. Обгрунтування методологічних підходів до здійснення санітарного контролю продуктів овочівництва та грунту при застосуванні сумішей пестицидів. Медична наука України. 2015. Т. 11. № 1-2. C. 84-90.

11. Vavrinevych O.P., Antonenko A.M., Omelchuk S.T. [et al.]. Prediction of pesticide risks to human health by drinking water extracted from underground sources. Georgian medical news. 2015. № 5 (242). P. 77-84.

12. Spadotto C.A. Screening method for assessing pesticide leaching potential. Pesticidas: R. Ecotoxicol. Curitiba. 2002. Vol. 12. P. 69-78.

13. PPDB: Pesticide Properties Data Base. URL: http://sitem.herts.ac.uk/aeru/footprint/en/. (Date of access 18.09.2020).

DOI https://doi.org/10.30525/978-9934-588-81-5-2.44

\section{ПСИХОГІГІЕНІЧНІ МЕТОДИ КОРЕКЦІЇ ДОНОЗОЛОГІЧНИХ ПСИХІЧНИХ СТАНІВ У ДІТЕЙ 3 ВАДАМИ СЕНСОРНОЇ СИСТЕМИ}

Герасименко О. I. кандидат біологічних наук, доиент кафедри гігієни та екології № 1 Харківський національний медичний університет

Кателевська Н. М. кандидат медичних наук, дочент кафедри гігієни та екологї № 1 Харківський національний медичний університет

Богачова О. C. кандидат медичних наук, старший викладач кафедри гігієни та екології № 1 Харківський національний медичний університет

Колоша О. В. здобувач вищої освіти

Харківський національний медичний університет м. Харків, Украӥна

Забезпечення соціального благополуччя дітей з особливими потребами, зокрема, обумовленими патологією сенсорної системи, є ознакою держави, в якій гідний розвиток і захист прав іїі громадян забезпечується з дотриманням принципів демократії, рівності, миру, соціальної справедливості з урахуванням моральних засад та традиційних 